Endocrinol. Japon. 1986, 33 (4), 519-525

\title{
NOTE
}

\section{Response of Growth Hormone Release to Human Growth Hormone- Releasing Factor and Its Analogs in the Bovine}

\author{
Koichi HODATE, Tetsu JOHKE and Shinichi OHASHI* \\ National Institute of Animal Industry, Tsukuba Norindanchi P. O. Box 5, Ibaraki 305 \\ *Research Institute for Polymers and Textiles, Yatabe-machi, Ibaraki 305
}

\begin{abstract}
Responses of growth hormone $(\mathrm{GH})$ release to synthetic human growth hormone-releasing factor (hGRF)-44- $\mathrm{NH}_{2}$ analogs were determined, and the $\mathrm{GH}-$ releasing potency based on dose per $\mathrm{kg}$ of body weight (bw) was compared with that of hGRF-44- $\mathrm{NH}_{2}$ in female dairy calves. Four- and 12-month-old calves were injected intravenously with $0.25 \mu \mathrm{g}$ of hGRF-44- $\mathrm{NH}_{2}$ or its analogs per $\mathrm{kg}$ of bw. Blood samples were collected before, and during $180 \mathrm{~min}$ after each injection, and plasma GH concentrations were measured by radioimmunoassay. Areas under the $\mathrm{GH}$ response curves for $180 \mathrm{~min}$ after injection of hGRF-44-NH $\mathrm{NH}_{2}$ and its analogs were used as an index of the GH-releasing potency of each peptide. The GH-releasing potency of hGRF(1-26)- $\mathrm{NH}_{2}$ was significantly lower than that of hGRF-44-NH $\mathrm{NH}_{2}(\mathrm{P}<0.05)$. On the other hand, hGRF(1-29)-NH $\mathrm{NH}_{2}$ possessed similar potency to hGRF-44-NH $\mathrm{NH}_{2}$ [D-Tyr ${ }^{1}$-hGRF44- $\mathrm{NH}_{2}$ showed prolonged GH-releasing activity, though its potency was similar to that of hGRF-44-NH . Also, [D-Ala $\left.{ }^{2}\right]-h G R F(1-29)-\mathrm{NH}_{2}$ exhibited prolonged GH-releasing activity, and its potency was $2.5(\mathrm{P}<0.05)$ and twice $(\mathrm{P}<0.05)$ as great as that of hGRF-44-NH $\mathrm{NH}_{2}$ and hGRF(1-29)- $\mathrm{NH}_{2}$, respectively. These results demonstrate that the N-terminal 29 amino acid residues of hGRF possess the activity site required for full $\mathrm{GH}$ release in vivo, and [D-Ala ${ }^{2}$ hGRF(1-29)- $\mathrm{NH}_{2}$ has longer and greater activity, on a dose basis, than hGRF$44-\mathrm{NH}_{2}$ in the calves.
\end{abstract}

Recently, growth hormone-releasing factors (GRFs) have been isolated, purified and characterized (Guillemin et al., 1984). Synthetic human GRF (hGRF)-44- $\mathrm{NH}_{2}$ specifically stimulates the release of growth hormone $(\mathrm{GH})$ in humans (Guillemin et al., 1984), rats (Guillemin et al., 1984), rabbits (Chihara et al., 1984), chickens (Leung and Taylor, 1983; Harvey and Scanes, 1984), goats (Hodate et al., 1984, 1985a; Hart

Received February 10, 1986 et al., 1984), sheep (Hodate et al., 1985a), cattle (Hodate et al., 1984; Johke et al., 1984 ; Moseley et al., 1984) and pigs (Hodate et al., 1985b). To elucidate the structureactivity relationships of GRFs, the relative GH-releasing potencies of several kinds of analogs or fragments of hGRF-44- $\mathrm{NH}_{2}$ have been studied mainly in the rat (Guillemin et al., 1984; Rivier et al., 1982; Wehrenberg and Ling, 1983; Ling et al., 1984; Ohashi et al., 1984; Lance et al., 1984; Heiman et al., 1985) and also in domestic 
animals (Hodate et al., 1985c; Lance et al., 1984; McCutcheon et al., 1984). In the rat, Rivier et al. (1982) found that hGRF (1-29)- $\mathrm{NH}_{2}$ has full intrinsic GH-releasing potency in vitro. Lance et al. (1984) reported that [D-Ala ${ }^{2}$-hGRF(1-29)- $\mathrm{NH}_{2}$ was approximately 50 times more potent than hGRF(1-29)- $\mathrm{NH}_{2}$ in eliciting GH secretion in vivo. The $\mathrm{GH}$ responses to hGRF(1-29)$\mathrm{NH}_{2}$ in lactating cows (McCutcheon et al., 1984) and pigs (Lance et al., 1984; Kraft et al., 1985) and to [D-Ala $]$-hGRF(1-29)$\mathrm{NH}_{2}$ in pigs (Lance et al., 1984) have been also determined. However, the relative GHreleasing potencies of these peptides to hGRF-44- $\mathrm{NH}_{2}$ are not known in the farm animals.

In the present experiments, we studied the GH-releasing potencies of hGRF(1-29)$\mathrm{NH}_{2}$, hGRF(1-26)-NH, [D-Ala $]$-hGRF(129) $-\mathrm{NH}_{2}$, [D-Tyr ${ }^{1}$-hGRF-44-NH $\mathrm{NH}_{2}$ and hGRF $-44-\mathrm{NH}_{2}$ in female dairy calves.

\section{Materials and Methods}

\section{Experimental animals}

Four 4-month-old and eight 12-month-old Holstein female dairy calves, $128 \mathrm{~kg}$ and $330 \mathrm{~kg}$ mean body weight (bw) respectively, from the institute herd were used. The animals were fed at $0830 \mathrm{~h}$, and synthetic hGRF-44- $\mathrm{NH}_{2}$, its analogs, or saline were given at $1100 \mathrm{~h}$.

Preparations of synthetic $h \mathrm{GRF}-44-\mathrm{NH}_{2}$ and its analogs for injection

The hGRF-44-NH $\mathrm{N}_{2}$ and its analogs: hGRF (1-26)- $\mathrm{NH}_{2}$ and hGRF(1-29)- $\mathrm{NH}_{2}$, fragments with 18 and 15 amino acids deleted from the $\mathrm{C}$ terminal of hGRF-44-NH ${ }_{2}$ respectively; [D-Tyr ${ }^{1}$ ]hGRF-44- $\mathrm{NH}_{2}$, an analog with D-Tyr substitution in N-terminal Tyr of hGRF-44-NH $\mathrm{NH}_{2}$; [D$\mathrm{Ala}^{2}$ ]-hGRF(1-29)- $\mathrm{NH}_{2}$, an analog with D-Ala substitution in position-2 Ala of hGRF(1-29)$\mathrm{NH}_{2}$, were synthesized by the solid-phase method and purified by HPLC (Ohashi et al., 1984). These preparations were dissolved in $3 \mathrm{ml}$ of sterilized saline before use and injected intravenously (iv) through an indwelling catheter inserted into one of the external jugular veins.

\section{Blood sampling methoa}

The jugular venous blood of the experimental animals was taken from an indwelling catheter previously inserted into one of the external jugular veins. The blood samples were collected before, and during over a period of $180 \mathrm{~min}$ immediately following the injection of hGRF-44$\mathrm{NH}_{2}$ and its analogs, or saline. Serial 3-4 ml blood samples were collected into centrifuge tubes containing heparin, and immediately chilled with ice. Individual plasma samples were obtained after centrifugation and stored at $-60^{\circ} \mathrm{C}$ until assayed.

\section{Measurement of plasma $G H$ and statistical a- nalysis}

The concentrations of plasma GH were determined by radioimmunoassay (Johke, 1978). Areas under the GH response curves for 180 min after each injection were determined and regarded as the total amount of $\mathrm{GH}$ released in response to hGRF-44-NH $\mathrm{NH}_{2}$ its analogs, or saline. These areas under the $\mathrm{GH}$ response curves were used as an index of the GH-releasing potency of each peptide. The paired $t$-test was used to assess the significance of the differences in the data (Snedecor and Cochran, 1980).

$G H$ responses to a single injection of $h G R F-44-$ $\mathrm{NH}_{2}, h \mathrm{GRF}(1-26)-\mathrm{NH}_{2}$, and [D-Tyr $\left.{ }^{1}\right]-h G R F-44-$ $\mathrm{NH}_{2}$

Four 4-month-old calves were injected iv with $0.25 \mu \mathrm{g}$ of hGRF-44-NH $\mathrm{N}_{2}, \mathrm{hGRF}(1-26)-\mathrm{NH}_{2}$, or [D-Tyr ${ }^{1}$-hGRF-44-NH $\mathrm{NH}_{2}$ per $\mathrm{kg}$ of bw, and $3 \mathrm{ml}$ saline (as a control). These experimental animals were repeatedly used for each treatment. The blood samples were drawn at $-10,0,5,10,20$, $30,45,60,90,120,150$ and $180 \mathrm{~min}$ after injection. The blood sample at 0 min was obtained just before each injection. The experiments were carried out between late March and early April, and treatments were carried out at 1-week intervals.

$G H$ responses to a single injection of $h G R F-44$ $\mathrm{NH}_{2}, h G R F(1-29)-\mathrm{NH}_{2}$, and [D-Ala $]-h G R F(1-29)-$ $\mathrm{NH}_{2}$

Eight 12-month-old calves were divided into two equal groups. The four calves $(337 \mathrm{~kg}$ mean bw) in one group were given a single iv injection of $0.25 \mu \mathrm{g}$ of hGRF-44-NH $\mathrm{NH}_{2}$ hGRF(129)- $\mathrm{NH}_{2}$, or [D-Ala $]$-hGRF(1-29)- $\mathrm{NH}_{2}$ per $\mathrm{kg}$ of bw. These animals were repeatedly used for 
each treatment. The blood samples were drawn at $-30,-15,0,5,10,15,20,30,45,60,90$, 120,150 , and $180 \mathrm{~min}$ after injection. In another group ( $322 \mathrm{~kg}$ mean bw), $3 \mathrm{ml}$ saline (as a control) was injected iv into each of the four calves. The blood samples were drawn at 15-min intervals. The experiments were carried out between late November and early December, and treatments were carried out a 1-week intervals.

\section{Results}

GH responses to $h G R F-44-\mathrm{NH}_{2}, \quad h G R F(1-$ 26) $-\mathrm{NH}_{2}$, and [D-Tyr $\left.r^{1}\right]-h G R F-44-\mathrm{NH}_{2}$

The responses of plasma $\mathrm{GH}$ in the 4month-old calves to a single injection of
hGRF-44-NH $\mathrm{NH}_{2}, \mathrm{hGRF}(1-26)-\mathrm{NH}_{2}$ and [D$\mathrm{Tyr}^{1}$ ]-hGRF-44-NH $\mathrm{N}_{2}$, or saline are shown in Fig. 1. Table 1 shows the areas under the GH response curves for $180 \mathrm{~min}$ after injection of each peptide or saline.

The mean plasma $\mathrm{GH}$ concentration in each saline injected control calf varied within the range 2.8 to $6.8 \mathrm{ng} / \mathrm{ml}$, and no elevation of the plasma GH level after injection was detected throughout the blood sampling period. In contrast, the concentration of plasma $\mathrm{GH}$ after the injection of hGRF-44- $\mathrm{NH}_{2}$ increased from the value of $4.5 \pm 0.5 \mathrm{ng} / \mathrm{ml}($ Mean $\pm \mathrm{SE})$ at $0 \mathrm{~min}$ to a maximum value of $107.2 \pm 37.8 \mathrm{ng} / \mathrm{ml}(\mathrm{P}<$ 0.05 ) at $10 \mathrm{~min}$.

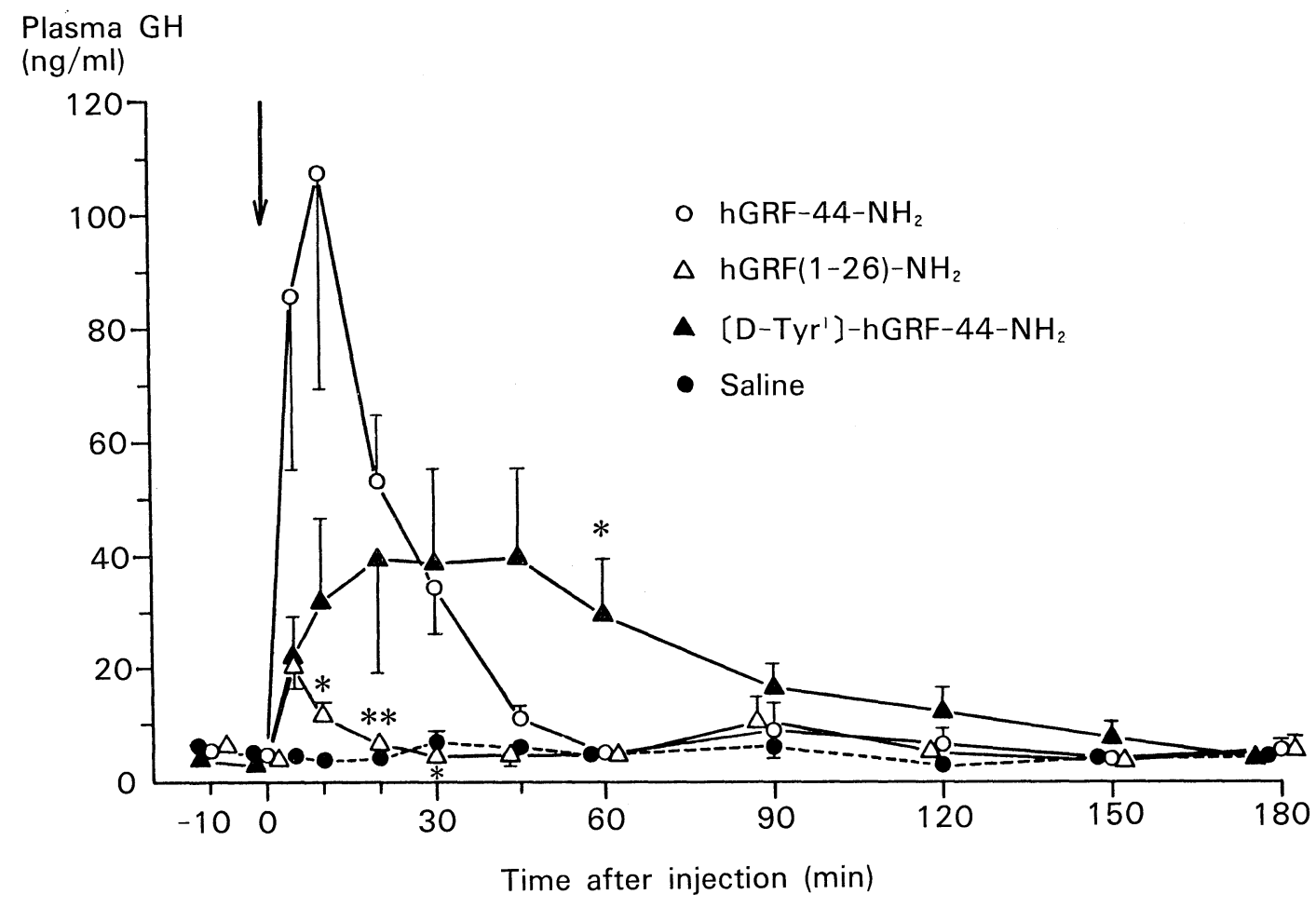

Fig. 1. Plasma GH responses to a single injection of hGRF-44-NH $(\bigcirc)$, hGRF(1-26)-NH2 $(\triangle)$ and $\left[\mathrm{D}-\mathrm{Tyy}^{1}\right]$-hGRF-44-NH $\mathrm{H}_{2}(\mathbf{\Delta})$, or saline $(\mathbf{O})$ in 4-month-old calves. An arrow indicates the time of peptide $(0.25 \mu \mathrm{g}$ per $\mathrm{kg}$ of $\mathrm{bw})$ or saline injection. Asterisks indicate the statistical differences; $* \mathbf{P}<0.05, * * \mathbf{P}<0.01$ as compared with the corresponding levels of hGRF-44-NH . Each point with a bar represents the mean $\pm \mathrm{SE}(\mathrm{n}=4)$. 
Table 1. Area under GH response curve for $180 \mathrm{~min}$ after injection of saline, hGRF-44- $\mathrm{NH}_{2}$ and its analogs in calves (4- and 12-month-old). The value is expressed as mean $\pm \mathrm{SE}(\mathrm{n}=4)$. Asterisks indicate the statistical difference; $* \mathbf{P}<0.05$ as compared with the value of hGRF-44- $\mathrm{NH}_{2}$ in each group.

\begin{tabular}{|c|c|c|}
\hline \multirow{2}{*}{ Treatment } & \multicolumn{2}{|c|}{ Area $(\mathrm{ng} \cdot \mathrm{min} / \mathrm{ml})$} \\
\hline & 4-month-old & 12-month-old \\
\hline Saline & $809.9 \pm 83.9^{*}$ & $683.4 \pm 128.9^{*}$ \\
\hline hGRF-44-NH ${ }_{2}$ & $3,022.4 \pm 606.7$ & $2,165.4 \pm 703.5$ \\
\hline hGRF(1-26)- $\mathrm{NH}_{2}$ & $1,162.6 \pm 208.6^{*}$ & - \\
\hline $\mathrm{hGRF}(1-29)-\mathrm{NH}_{2}$ & $3616 \overline{6+4278}$ & $2,670.1 \pm 305.7$ \\
\hline [D-Ala $]$-hGRF(1-29)-NH & $\frac{0,010.0 \pm 421.8}{-}$ & $5,407.3 \pm 922.8^{*}$ \\
\hline
\end{tabular}

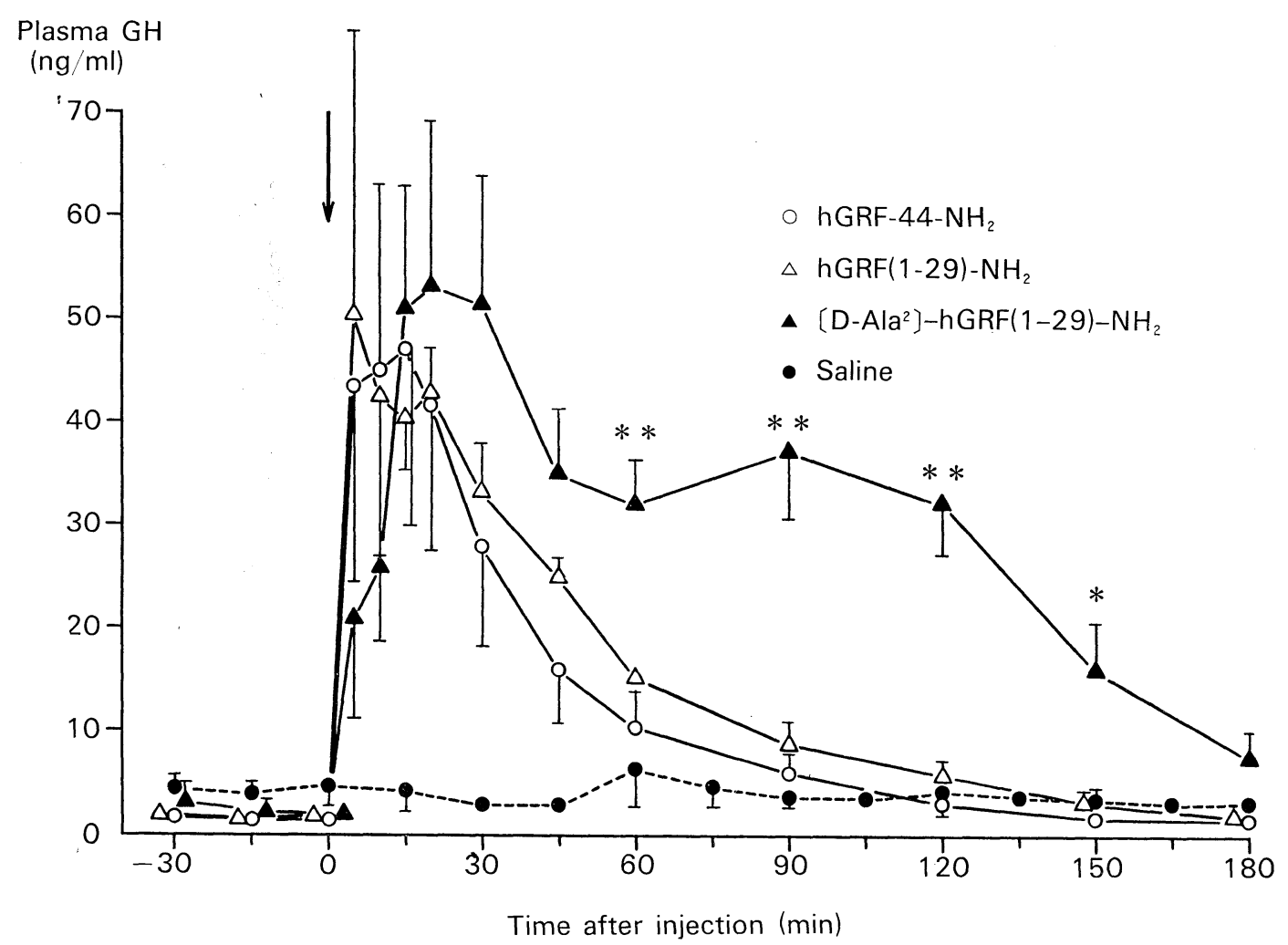

Fig. 2. Plasma GH responses to a single injection of hGRF-44-NH $\mathrm{NH}_{2}(\bigcirc), \mathrm{hGRF}(1-29)-\mathrm{NH}_{2}$ $(\triangle)$ and $\left[\mathrm{D}-\mathrm{Ala}^{2}\right]-\mathrm{hGRF}(1-29)-\mathrm{NH}_{2}(\boldsymbol{\Delta})$, or saline $(\mathbf{O})$ in 12-month-old calves. An arrow indicates the time of peptide $(0.25 \mu \mathrm{g}$ per $\mathrm{kg}$ of bw) or saline injection. Asterisks indicate the statistical differences; ${ }^{*} \mathbf{P}<0.05, * * \mathbf{P}<0.01$ as compared with the corresponding levels of hGRF-44-NH2. Each point with a bar represents the mean $\pm \mathrm{SE}(\mathrm{n}=4)$. 
Injection of hGRF(1-26)- $\mathrm{NH}_{2}$ caused an elevation in the plasma $\mathrm{GH}$ level from the value of $4.7 \pm 0.5 \mathrm{ng} / \mathrm{ml}$ at $0 \mathrm{~min}$ to a peak value of $20.1 \pm 3.9 \mathrm{ng} / \mathrm{ml}(\mathrm{P}<0.05)$ at $5 \mathrm{~min}$. The peak value was only $19 \%$ of the peak produced by hGRF-44-NH $\mathrm{NH}_{2}$. The concentrations of $\mathrm{GH}$ at 10,20 and $30 \mathrm{~min}$ in the calves given this fragment were significantly lower $(\mathrm{P}<0.05)$ than the corresponding concentrations of $\mathrm{GH}$ in the calves given hGRF44- $\mathrm{NH}_{2}$. Also, the area under the $\mathrm{GH}$ response curve was significantly smaller $(\mathrm{P}<$ $0.05)$ than that obtained by hGRF-44- $\mathrm{NH}_{2}$.

Injection of [D-Tyr ${ }^{1}$-hGRF-44-NH $\mathrm{NH}_{2}$ also caused a significant increase in the plasma $\mathrm{GH}$ level from the value of $2.9 \pm 0.4 \mathrm{ng} / \mathrm{ml}$ at $0 \mathrm{~min}$ to a maximum value of $39.6 \pm 15.6$ $\mathrm{ng} / \mathrm{ml}(\mathrm{P}<0.05)$ at $45 \mathrm{~min}$. The plasma level for $\mathrm{GH}$ at $60 \mathrm{~min}(29.7 \pm 9.7 \mathrm{ng} / \mathrm{ml})$ was significantly higher $(\mathrm{P}<0.05)$ than the corresponding value for $\mathrm{GH}(4.8 \pm 0.7 \mathrm{ng} / \mathrm{ml})$ in the animals given hGRF-44-NH $\mathrm{NH}_{2}$ Although the maximum plasma concentration of $\mathrm{GH}$ in the calves given this analog was $37 \%$ of that produced by hGRF-44- $\mathrm{NH}_{2}$, the area under the $\mathrm{GH}$ response curve was larger than that obtained by hGRF-44- $\mathrm{NH}_{2}$, though neither the difference between the maximum values nor the difference between the areas was statistically significant.

GH responses to hGRF-44-NH $\mathrm{NH}_{2}, h G R F(1-29)$ $\mathrm{NH}_{2}$, and [D-Ala $]-h G R F(1-29)-\mathrm{NH}_{2}$

Fig. 2 and Table 1 show the responses of $\mathrm{GH}$ release in the 12 -month-old calves to a single injection of hGRF-44- $\mathrm{NH}_{2}$, hGRF(1-29)- $\mathrm{NH}_{2}$ and [D-Ala ${ }^{2}$-hGRF(1-29)$\mathrm{NH}_{2}$, or saline and the areas under the $\mathrm{GH}$ response curves for $180 \mathrm{~min}$ after injection of each peptide or saline, respectively.

The mean plasma $\mathrm{GH}$ concentration in each saline injected control calf varied within the range 2.8 to $6.3 \mathrm{ng} / \mathrm{ml}$, and no elevation of the plasma GH level after injection was detected throughout the blood sampling period.

The concentration of $\mathrm{GH}$ after injection of hGRF-44- $\mathrm{NH}_{2}$ rose to a maximum value of $47.0 \pm 17.1 \mathrm{ng} / \mathrm{ml} \quad(\mathrm{P}<0.05)$ at $15 \mathrm{~min}$ from $1.4 \pm 0.2 \mathrm{ng} / \mathrm{ml}$ at $0 \mathrm{~min}$. Also, injection of hGRF(1-29)- $\mathrm{NH}_{2}$ caused a significant increase $(\mathrm{P}<0.05)$ in the plasma $\mathrm{GH}$ up to the level produced by hGRF-44-NH $\mathrm{NH}_{2}$ Both the response of plasma $\mathrm{GH}$ and the area under the $\mathrm{GH}$ response curve in the calves given hGRF(1-29)- $\mathrm{NH}_{2}$ were very similar to those of $\mathrm{GH}$ in the calves injected with hGRF-44- $\mathrm{NH}_{2}$.

The plasma GH concentration after [D$\left.\mathrm{Ala}^{2}\right]$-hGRF(1-29)- $\mathrm{NH}_{2}$ injection increased from $2.0 \pm 0.6 \mathrm{ng} / \mathrm{ml}$ at $0 \mathrm{~min}$ to a maximum of $53.2 \pm 16.0 \mathrm{ng} / \mathrm{ml}(\mathrm{P}<0.05)$ at $20 \mathrm{~min}$, and then continued above $30 \mathrm{ng} / \mathrm{ml}$ until $120 \mathrm{~min}$. The concentrations of $\mathrm{GH}$ at 60-150 min were significantly higher $(\mathrm{P}<$ 0.05) than the corresponding values for $\mathrm{GH}$ in the calves given hGRF-44-NH $\mathrm{NH}_{2}$. Although the maximum level of $\mathrm{GH}$ obtained after this analog injection was similar to that produced by hGRF-44-NH $\mathrm{NH}_{2}$ and hGRF (1-29) $-\mathrm{NH}_{2}$, the area under the $\mathrm{GH}$ response curve was $2.5(\mathrm{P}<0.05)$ and twice $(\mathrm{P}<0.05)$ as large as that obtained by hGRF-44- $\mathrm{NH}_{2}$ and hGRF(1-29)- $\mathrm{NH}_{2}$, respectively.

\section{Discussion}

Our results demonstrate that an analog with D-Ala substitution in position-2 Ala of hGRF(1-29)- $\mathrm{NH}_{2}$, [D-Ala $]$-hGRF(1-29)$\mathrm{NH}_{2}$, exhibits the prolongation of $\mathrm{GH}-$ releasing activity and a significant increase in potency based on dose per $\mathrm{kg}$ of bw compared with that of hGRF-44- $\mathrm{NH}_{2}$ or hGRF(1-29)- $\mathrm{NH}_{2}$ in the 12-month-old calves. Similar phenomena were also observed in the lactating cows (Johke et al., unpublished data) and goats (Hodate et al., unpublished data). In the rat, this analog was approximately 50 times more potent than hGRF(1-29)- $\mathrm{NH}_{2}$ in eliciting $\mathrm{GH}$ secretion both in vivo (Lance et al., 1984) and in vitro (Heiman et al., 1985). The reason for the 
increased in vivo GH-releasing potency of [D-Ala ${ }^{2}$-hGRF(1-29)- $\mathrm{NH}_{2}$ in the calves is not known, but the increased potency could be ascribed either to the increased biological half-life or the increased affinity of the receptor to this peptide.

Although [D-Tyr ${ }^{1}$ ]-hGRF-44- $\mathrm{NH}_{2}$ showed prolonged GH-releasing activity compared with hGRF-44- $\mathrm{NH}_{2}$ in the 4-month-old calves, its potency was similar to that of hGRF-44-NH $\mathrm{N}_{2}$. This result agreed with the in vivo result reported previously in 10month-old calves or wethers (Hodate et al., $1985 \mathrm{c}$ ) and the in vitro result in the rat (Ohashi et al., 1984).

Our results also demonstrate that deletion of 18 amino acids from the C-terminal of hGRF-44- $\mathrm{NH}_{2}$ causes a significant decrease in the in vivo GH-releasing potency in calves, but deletion of 15 amino acids does not reduce the potency. In the rat, deletion of as many as 13 amino acids failed to reduce the in vivo GH-releasing activity; however, deletion of 16 amino acids resulted in a significant decrease (Wehrenberg and Ling, 1983). Moreover, it has been reported that hGRF(1-29)- $\mathrm{NH}_{2}$ is approximately one half as potent as hGRF(1-40)-OH in the in vivo assay in the rat (Lance et al., 1984), but has similar potency to hGRF(1-40)-OH when tested in vitro with rat pituitary cell cultures (Rivier et al., 1982). In a previous study, we suggested that the amino acid residues above 27 from the $\mathrm{N}$-terminal of hGRF-44- $\mathrm{NH}_{2}$ are essential for exerting sufficient GRF activity in vivo in cattle and sheep (Hodate et al., 1985c). The present results support the above findings, and suggest that the N-terminal 29 amino acid residues of hGRF possess the activity site required for full bovine $\mathrm{GH}$ release in vivo.

In previous studies, the responses of $\mathrm{GH}$ release to hGRF-44- $\mathrm{NH}_{2}$ in cattle (Johke et al., 1984), goats (Hodate et al., 1985a) and sheep (Hodate et al., 1985a) have been shown to decrease with advancing age. Both the peak level of plasma $\mathrm{GH}$ and the area under the $\mathrm{GH}$ response curve for $180 \mathrm{~min}$ after injection of hGRF-44- $\mathrm{NH}_{2}$ in the 4month-old calves tended to be larger than in the 12-month-old calves, though the differences were not statistically significant in the present experiments. In cattle, it has been reported that the basal GH level and peak level of plasma $\mathrm{GH}$ after injection of thyrotropin releasing hormone did not differ significantly between May and October (Johke, 1978). Therefore, the response of bovine $\mathrm{GH}$ release to hGRF-44- $\mathrm{NH}_{2}$ may not be affected by the season.

We conclude that, on the basis of the dose per $\mathrm{kg}$ of $\mathrm{bw}$, the in vivo $\mathrm{GH}$-releasing potency of $\mathrm{hGRF}(1-29)-\mathrm{NH}_{2}$ is equal to that of hGRF-44-NH $\mathrm{NH}_{2}$, and [D-Ala ]-hGRF(129) $-\mathrm{NH}_{2}$ has longer and greater activity than hGRF-44- $\mathrm{NH}_{2}$ or hGRF(1-29)- $\mathrm{NH}_{2}$ in stimulating $\mathrm{GH}$ release in calves.

\section{Acknowledgements}

The authors are grateful to NIAMDD, U.S.A., and Professor C. H. Li, University of California, for the generous gift of purified bovine $\mathrm{GH}$. The authors wish to thank Mr. A. Kawabata and Mr. H. Fuse for their valuable assistance.

\section{References}

Chihara, K., N. Minamitani, H. Kaji, H. Kodama, T. Kita and T. Fujita (1984). Noradrenergic modulation of human pancreatic growth hormone-releasing factor (hpGRF1-44)-induced growth hormone release in conscious male rabbits: involvement of endogenous somatostatin. Endocrinology 114, 1402-1406.

Guillemin, R., F. Zeytin, N. Ling, P. Böhlen, F. Esch, P. Brazeau, B. Bloch and W. B. Wehrenberg (1984). Growth hormone-releasing factor: chemistry and physiology. Proc. Soc. Exp. Biol. Med. 175, 407-413.

Hart, I. C., S. James, B. N. Perry and A. D. Simmonds (1984). Effect of intravenous administration of growth hormone-releasing factor (hpGRF-44) and Tyr-D-Trp-Ala-Trp-D-Phe$\mathrm{NH}_{2}$ on plasma hormones and metabolites in 
goats. J. Endocr. 103, 173-178.

Harvey, S. and C. G. Scanes (1984). Comparative stimulation of growth hormone secretion in anaesthetized chickens by human pancreatic growth hormone-releasing factor (hpGRF) and thyrotrophin-releasing hormone (TRH). Neuroendocrinology 39, 314-320.

Heiman, M. L., M. V. Nekola, W. A. Murphy, V. A. Lance and D. H. Coy (1985). An extremely sensitive in vitro model for elucidating structure-activity relationships of growth hormone-releasing factor analogs. Endocrinology 116, 410-415.

Hodate, K., T. Johke, A. Kawabata, S. Ohashi, M. Shiraki and S. Sawano (1984). Effect of synthetic growth hormone-releasing factor from a human pancreatic tumor on bovine and caprine growth hormone secretion. Jpn. J. Zootech. Sci. 55, 66-68.

Hodate, K., T. Johke, A. Kawabata, H. Fuse, S. Ohashi, M. Shiraki and S. Sawano (1985a). Influences of dose, age and sex on plasma growth hormone response in goats and sheep to synthetic human growth hormone-releasing factor. Jpn. J. Zootech. Sci. 56, 41-48.

Hodate, K., T. Johke, A. Kawabata, H. Fuse, S. Ohashi, M. Shiraki and S. Sawano (1985b). Effect of synthetic human growth hormonereleasing factor on growth hormone release in swine. Bull. Nat. Inst. Anim. Ind. (submitted, in Japanese)

Hodate, K., T. Johke, A. Kawabata, H. Fuse, S. Ohashi, M. Shiraki and S. Sawano (1985c). Effects of human growth hormone-releasing factor and its analogs on growth hormone secretion in cattle and sheep. Jpn. J. Zootech. Sci. 56, 744-750.

Johke, T. (1978). Effects of TRH on circulating growth hormone, prolactin and triiodothyronine levels in the bovine. Endocrinol. Japon. 25, 19-26.

Johke, T., K. Hodate, S. Ohashi, M. Shiraki and S. Sawano (1984). Growth hormone response to human pancreatic growth hormone releasing factor in cattle. Endocrinol. Japon. 31, 55-61.

Kraft, L. A., P. K. Baker, C. A. Ricks, V. A. Lance, W. A. Murphy and D. H. Coy (1985). Stimulation of growth hormone release in anesthetized and conscious pigs by synthetic human pancreatic growth hormone-releasing factor [hpGRF(1-29)- $\left.\mathrm{NH}_{2}\right]$. Domestic Anim. Endocr. 2, 133-139.

Lance, V. A., W. A. Murphy, J. Sueiras-Diaz and D. H. Coy (1984). Super-active analogs of growth hormone-releasing factor (1-29)amide. Biochem. Biophys. Res. Commun. 119, 265-272.

Leung, F. C. and J. E. Taylor (1983). In vivo and in vitro stimulation of growth hormone release in chickens by synthetic human pancreatic growth hormone releasing factor (hpGRFs). Endocrinology 113, 1913-1915.

Ling, N., A. Baird, W. B. Wehrenberg, N. Ueno, T. Munegumi, T.-C. Chiang, M. Regno and P. Brazeau (1984). Synthesis and in vivo bioactivity of human growth hormone-releasing factor analogs substituted at position-1. Biochem. Biophys. Res. Commun. 122, 304-310.

McCutcheon, S. N., D. E. Bauman, W. A. Murphy, V. A. Lance and D. H. Coy (1984). Effect of synthetic human pancreatic growth hormone-releasing factors on plasma growth hormone concentrations in lactating cows. $J$. Dairy Sci. 67, 2881-2886.

Moseley, W. M., L. F. Krabill, A. R. Friedman and R. F. Olsen (1984). Growth hormone response of steers injected with synthetic human pancreatic growth hormone-releasing factors. J. Anim. Sci. 58, 430-435.

Ohashi, S., K. Ohtaka, M. Shiraki, S. Sawano, S. Ozaki, M. Mori and T. Takaoka (1984). Synthesis of hpGRF-44 and its analogs. Peptide Chemistry 1983, 291-296.

Rivier, J., J. Spiess, M. Thorner and W. Vale (1982). Characterization of a growth hormonereleasing factor from a human pancreatic islet tumor. Nature 300, 276-278.

Snedecor, G. W. and W. G. Cochran (1980). Statistical Methods, 7th ed., The Iowa State University Press, Ames. Iowa, U. S. A. pp. 83-106.

Wehrenberg, W. B. and N. Ling (1983). In vivo biological potency of rat and human growth hormone-releasing factor and fragments of human growth hormone-releasing factor. Biochem. Biophys. Res. Commun. 115, 525-530. 